\title{
In Tribute to James A. Wilkerson III, MD
}

The purpose of life is . . to be useful, to be honorable, to be compassionate, to have it make some difference that you have lived and lived well.

$$
\text { —Ralph Waldo Emerson }
$$

The field of wilderness medicine has many heroes, but not many quite as prolific as James A. Wilkerson III, MD. An author, instructor, and truly kind gentleman, Jim touched most of us in one way or another. He received his medical degree from John Hopkins in 1958, completed a Fellowship at the Ronald Regan UCLA Medical Center in 1965, and had a successful pathology practice in Merced, California. Jim edited the prolific book Medicine for Mountaineering published in 1967 when the field of wilderness and mountain medicine was in its earliest stages. In 1986, he then authored the book $\mathrm{Hy}$ pothermia and Cold Injuries with Cam Bangs and John Hayward. Twenty years later, Gordon Giesbrecht and Jim together completed a second edition of the book which is widely read and cited today.

A copy of Medicine for Mountaineering sits on the bookshelf behind me in my home office. Although more of a textbook than a quick reference, I would nonetheless bring it on Outward Bound courses that I instructed many years ago. I would read entire chapters to the group as if it were a storybook - a way to pass on my enthusiasm about mountain medicine to my students. They were fascinated by how simple but practical the care of patients could be in the outdoor setting. The medical pictures, a few in particular, were quick and easy-toassimilate snapshots of wilderness treatments and preventions.

I first was introduced to Jim when he moved to Park City. He quickly became involved in the Wilderness Medical Society (WMS) Park City conference and continued to be an integral part of the Society. The Wilderness \& Environmental Medicine Journal awarded Jim the first "Outstanding Contributor" award at the 2011 Snowmass Conference for his reviews, keen insights, and dedication to the Journal. A couple of weeks before the conference, he informed us that he could not accept the award in person because he had not been feeling well and was to undergo some tests. Details were few at that point, and we waited for updates. Sadly, on Friday, April 13, 2012, Jim died from an aggressive form of cancer.

We always expect our heroes to simply cure themselves and keep on going. Alas, the world does not

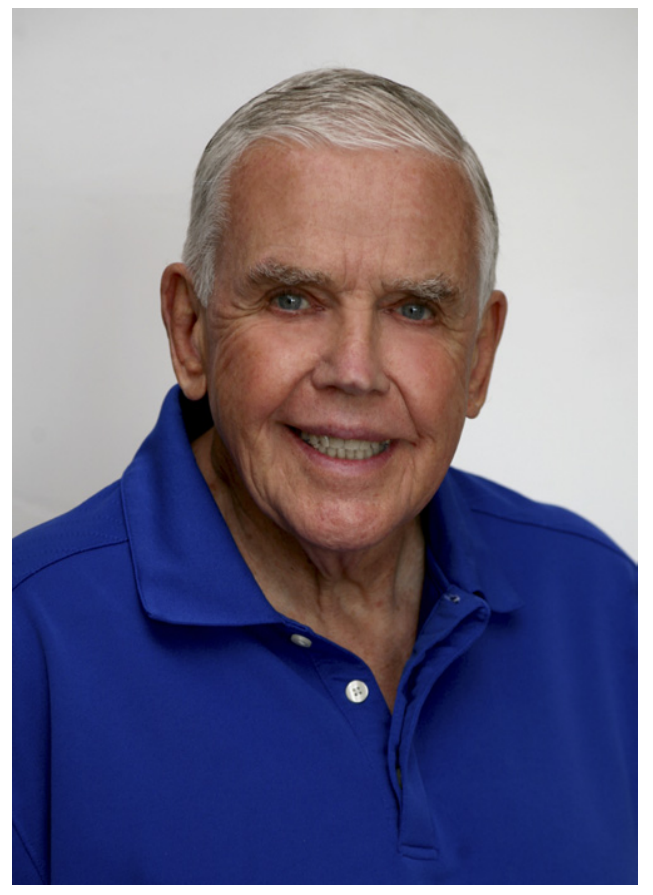

usually work that way. Jim will always be our mentor and hero.

Scott E. McIntosh, MD, MPH Editor-in-Chief

Wilderness \& Environmental Medicine

Associate Professor, Division of Emergency Medicine Director, EMS/Wilderness Medicine Fellowship,

University of Utah

Salt Lake City, UT

For those of us who claim wilderness medicine as an integral part of our soul, know we do so because of the inspiring influence of individuals with whom our paths in life have crossed. For me, wilderness medicine has added so many new dimensions to my love for life itself. I owe much of this to my friend and mentor Jim Wilkerson.

I cannot recall in detail those circumstances which inspired me to attend my first wilderness medicine conference in Peru in August of 2000; however, it was there that a lifelong passion for wilderness medicine took root in my heart and where I forged a cherished and invaluable friendship with Jim. Whether a twist of fate, a turn of chance, or something attributed to the magical mys- 
teries of the Incan ruins, this became first in a series of memories which will stand the test of time.

Jim spoke on water purification in the wilderness, of hypothermia, rabies and malaria-these topics, initially presented to me in Cusco, and were revisited in the many other wilderness medicine conferences. Jim was a worldrenowned expert on these topics. He was well published in various aspects of wilderness medicine and always inclined toward sharing his knowledge with those without a medical background, yet who also found solace in the wilderness. Jim was a humble man and never boastful of his works and valued contributions to the wilderness medicine canon.

As a devoted member of the WMS, Jim was committed to the betterment and survival of this organization which he loved. I remember many conversations over coffee, when he expressed concerns regarding the survival of the Society during times of financial crisis and tumult. He would think aloud and I would listen. He was steadfast in his commitment, both in his service on the Board and as a longstanding and active member of the WMS.

As a teacher and a mentor he both encouraged me and offered me opportunities to write on topics of wilderness medicine. He was a patient man as he guided me through the process of writing. I was fortunate to have opportunities to co-author chapters with Jim and he invited me to contribute chapters to his books on mountaineering. He loved organizing the "mini-weekend" wilderness medicine lectures and offered me the opportunity to speak on many occasions.

Outside of wilderness medicine, Jim was a family man; a loving father to his children and adoring of his wife, Sam. He always spoke proudly of his children's accomplishments and tenderly of Sam. He also was an excellent pathologist and enjoyed his work.

My last conversation with him was a gift. I did not know that I would lose the opportunity to spend a weekend visiting him and Sam during his last days - my scheduled flight was a week too late. Nevertheless, I had that one last chance to thank him for those gifts he had given to me; to thank him for the priceless treasure of a true friendship, for sharing his appreciation of wilderness medicine and for introducing me to others of kindred spirit.

On April $13^{\text {th }}$ of 2012, Jim passed on the baton in the relay of life to us who share in the interest of both preserving and extending the excellence of wilderness medicine. Jim will be missed.

Andrea R. Gravatt, MD Clinical Associate Professor Department of Pediatric Medicine
University of Washington School of Medicine

Seattle, WA

Back in the late 1970s when I was a young wilderness instructor and recreational climber, I was trying to build a library on wilderness topics. When I was looking for a medical text, I came upon Medicine for Mountaineering ( $2^{\text {nd }}$ edition, 1975$)$ by some guy named Wilkerson. I didn't know the name but read the whole book (as I can tell by highlighting throughout that text) and found the content extremely helpful, as literally hundreds of thousands of other readers have.

In the late 1980s I was thrilled to meet the man himself, James Wilkerson III, at a WMS conference. It got better from there as I was able to serve on the WMS board with him and then had the opportunity to actually contribute to a new edition of his iconic text. When Jim asked me to help rewrite a new edition of Hypothermia, Frostbite and Other Cold Injuries, I thought I'd died and gone to heaven... what a privilege! I was honored to just have my name on this book with him, but one day he showed how humble and generous he was. He suggested that since I had rewritten most of the book, I should be the first author of the new second edition. Wow, he didn't have to do that and I didn't expect it, but I will always remember this unselfish gesture, along with his immense mountain of knowledge about wilderness medicine.

Gordon Giesbrecht, $\mathrm{PhD}$
Former WMS Board Member
Editorial Board
Wilderness \& Environmental Medicine
Associate Dean (Special Projects)
Faculty of Kinesiology and Recreation Management,
University of Manitoba
Manitoba, Canada

Jim Wilkerson was woven into the fabric of wilderness medicine. He was a great man and a friend who provided inspiration to many generations of doctors, writers, scientists, and explorers. With a twinkle in his eye, he could challenge assumptions, wax eloquently on the esoterica of animal-borne communicable diseases, or offer an anecdote followed by a chuckle. Jim was generous with his time and wisdom, and despite the undoubtedly boring administrative tasks we floated in his direction while creating the WMS, he never complained. Jim lived for the details, the depth of understanding, and the satisfaction that comes with knowing his subject matter inside and out. He was about literary improvement before many of us learned how to put pen to paper which is precisely what Jim did, because his accomplishments were inaugurated long before there were 
personal computers. His dry sense of humor was usually in the offering if you paid attention to his facial expressions, which were sometimes subtle but never mistaken. Jim was a founder in every sense of the word - one of the first to offer detailed, useful medical advice to laypersons who loved the outdoors and a stalwart in support of the congregation that morphed into the specialty of wilderness medicine.

What I admired most about Jim were his abilities to pause and contemplate, and to not play favorites. Humility was his strong suit. There were a lot of choices to be made, and possible paths to take, and like a loyal and experienced trail horse, Jim always knew where he was headed. While the rest of us were galloping over rocks and scratching our skin on thorny bushes, Jim used a cadence to put one foot in front of another, never threw a shoe, and never broke a sweat. He was as gentle and unobtrusive a person as I have encountered, yet he heard everything, was a clear thinker, and was always a contributor. Jim gracefully commanded a presence, and we were very fortunate to have him among us.

Paul S. Auerbach, MD

Past President, Wilderness Medical Society Redlich Family Professor of Surgery Stanford University School of Medicine Stanford, $C A$

I first discovered the wisdom of Jim Wilkerson in 1967 when I acquired my copy of the first edition of his Medicine for Mountaineering. This was in the days when a handful of authors' names represented the foundations of medical knowledge among mountaineers. This little jewel of a book was written for the layman. Health professionals, however, devoured the text because the content was not available elsewhere in such a clear format except through experience of the participant.

There were no computers; no cell phones; no organizations dedicated to outdoor settings for medical education. Here is where Jim's skill as a communicator rose to the top. His personal traits, warm, friendly, and softspoken manner combined with the vast knowledge of his subject matter made him a classic information source for those in a learning setting

Where did these features and this information come from? This soft-spoken Southerner had lived in Alabama, Texas, Davis and Merced, California, and Park City, Utah. His colleagues knew him as a family man; through his wife, Sam, and children, and as a gentle but brilliant scholar, teacher, researcher, and humanitarian.

Fortunately for us all, the beginnings of the Wilderness Medical Society provided an ideal platform to which he was drafted. I was at the first annual meeting of the WMS and walked in to find Jim there quietly present at each faculty meeting, gently contributing rational help and opinions in his scholarly manner.

He served on the Board of Directors for eight years, was on the Education Committee and was Chair for many years, and was Chair of the Annual Meeting in 2000. He was Reviews Section Editor for Wilderness \& Environmental Medicine and was Editor of all six editions of Medicine for Mountaineering. He participated in the assessment of cold and injuries of the Mt. Hood avalanche disaster.

His ability to assimilate facts and present them made learning from Jim the ultimate. For the fourth and fifth editions, Jim asked me to update Dr Hultgren's (after his death) chapter on cardiology in the text Medicine for Mountaineering. He followed in the next (sixth) edition by asking my cardiologist son, Blair Jr, to collaborate with me, as an indication of his recognition of the importance of family tradition.

Jim was kind to all, a gentleman, true to himself, his family and his friends. His professional colleagues acknowledged his qualities by presenting him with the Paul S. Auerbach Award in Wilderness Medicine for his unique contributions.

As Ben Jonson said of Shakespeare:

He was (indeed) honest, and, of an open and free nature, had an excellent phantasy, brave notions, and gentle expressions.... ${ }^{1}$

Jim, we will miss you, but your gentle wisdom remains with us.

\section{Blair D. Erb, MD \\ Past President, Wilderness Medical Society \\ Townsend, TN}

James Wilkerson was a historic person in the development of wilderness medicine and a pivotal person in the operation of the WMS. He organized the first compendium on mountain medicine designed for a wide audience which subsequently introduced numerous wilderness enthusiasts to the basics of high altitude and remote area care. Many of the authors of chapters in his book Medicine for Mountaineering were inspired to become more active in the teaching of their craft.

And teaching the craft of wilderness medicine was an especially passionate love that Jim shared with the WMS. He took the lead in maintaining the Society's CME accreditation status - a truly immense job as Hill McBrayer now knows. He was a national Program Chair, but more importantly during my presidency, took on the task of forming regional WMS CME programs across the

1. Discoveries De Shakespeare. Nostrati Augustus in Haterium. 1641. 
country. He was a principle contributor to the WMS Practice Guidelines and to many WMS workshops and plenary lectures.

$\mathrm{He}$ and his wife Sam were stalwarts in providing email and website support and advice in the Society's early forays into the Internet. His energy and dedication to our Society knew no bounds.

I first met Jim when we were both lecturing at a small program in New Hampshire back in the early 1980s. It was an honor for me to meet him then, and I always looked forward to being with him ever after. I especially enjoyed hearing Jim lecture on one of his favorite topics, rabies, or simply to visit together at our functions. And I will never forget the night at one of our Keystone meetings when he hiked through the rain back to his room to get me some diamox as I was having a bit of altitude illness! He was a kind and gentle hearted mentor to many of us in the wilderness medicine field. It is people like him that make the Wilderness Medical Society the fun, informative, and inspirational group that it is. And it is a legacy such as that which lives on forever.

William W. Forgey, MD

Past President, Wilderness Medical Society Advisor, Medical Student Missions, Inc. Merrillville, IN

At first, to me Jim Wilkerson was the author of the major book on mountain medicine. He was obviously the authoritative, sage man who combined two of my passions: medicine and the mountains. The next thing I knew was that he was active in the WMS. Wow, I might get to meet him!

As it turned out, Jim was all the things I had thought he might be, but as I should have known, he was a lot more. Over the last 20 years, mostly through the WMS, I have interacted frequently and deeply with Jim. We were on the Board of Directors together and collaborated on teaching and administration activities.

During those many hours whether they were at WMS meetings, Cusco, Peru, or in the end of nowhere, I got to know Jim. His careful, thorough nature fit his career as a pathologist. He did not accept sloth, mediocrity, or unacceptable compromise. He could be canterkerous yet endearing. I got to know his softer side, his love for his wife, his love for wilderness.

He very much wanted to retire to Park City, and I remember his anticipation of moving there, his longing for that solitude and peace. He had some of that but far too little. But what I am thankful for is the opportunity to have Jim transcend from being the guy who wrote the book to a treasured colleague. On belay.

\section{Robert B. Schoene, MD \\ Past President, Wilderness Medical Society Alta Bates Medical Center Berkeley, $C A$}

I knew of James A. Wilkerson, MD long before I ever met him. I always carried a copy of Medicine for Mountaineering with me when working as a Colorado Outward Bound School Instructor in the early 1980s, before I entered medical school. I was fascinated by the information contained in the book that was not available anywhere else to a non-physician. This was in the days before the Internet, and it was not easy to search for answers to a medical problem. You had to have access to printed material, and Jim Wilkerson was ahead of his time when he put advanced-level medical information into a book dedicated to the non-health care professionals who might find themselves in a remote area dealing with a medical problem. This was my situation as an Outward Bound Instructor. In the early 1980s there were very few wilderness-oriented first responder courses, and most outdoor guides and trip leaders obtained their medical training from American Red Cross courses that were not wilderness oriented. Medicine for Mountaineering was my valued source of information to respond to medical problems in a remote area out of contact with the rest of the world. Remember, we did not have cell phones either in those days.

I finally met Jim in person after medical school and training when I was a young physician with wilderness medicine and altitude aspirations. I was inspired by how he came to be a visionary in providing opportunities for wilderness medicine education. Jim Wilkerson was a great example of what a physician could accomplish in wilderness medicine. The last part of my relationship with Jim entailed working alongside him as a colleague at the Wilderness Medical Society. Jim was an example of a leader in the Wilderness Medical Society who selflessly put hours of work into conference organization, running the Continuing Medical Education Committee, and serving as Review Articles Section Editor for Wilderness \& Environmental Medicine journal. He was a strong advocate for what he thought was best for the WMS and was always willing to do more. He was a major force behind the success of the Wilderness Medical Society, and we will miss him.

Colin K. Grissom, MD

Past President, Wilderness Medical Society

Shock Trauma ICU

Intermountain Medical Center

Murray, UT

Associate Professor of Medicine

University of Utah 